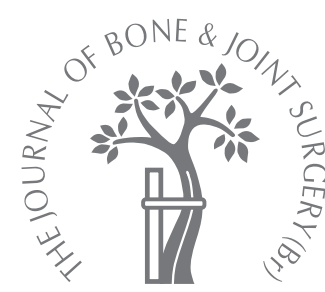

\title{
Chromium and cobalt ion release following the Durom high carbon content, forged metal-on-metal surface replacement of the hip
}

P.-A. Vendittoli, S. Mottard, A. G. Roy, C. Dupont, M. Lavigne

From MaisonneuveRosemont Hospital, Montréal University Montréal, Canada

P.-A. Vendittoli, MD, MSc, FRCS, Associated Professor of Surgery

A. G. Roy, MD, FRCS Associated Professor of Surgery

M. Lavigne, MD, FRCS Associated Professor of Surgery

Surgery Department - S. Mottard, MD, Orthopaedic Registrar C. Dupont, MSc, Statistician Maisonneuvé-Rosemont Hospital, Montreal University, 5415 Boulevard de I'Assomption, Montréal, Québec HIT 4B3, Canada.

Correspondence should be sen to Mr P.-A. Vendittoli; e-mail: pa.vendittoli@videotron.ca

(C2007 British Editorial Society of Bone and Joint Surgery doi:10.1302/0301-620X.89B4 $18054 \$ 2.00$

$J$ Bone Joint Surg $[\mathrm{Br}]$ 2007:89-B:441-8.

Received 25 April 2006 Accepted after revision 6 December 2006

\begin{abstract}
We evaluated the concentrations of chromium and cobalt ions in blood after metal-on-metal surface replacement arthroplasty using a wrought-forged, high carbon content chromiumcobalt alloy implant in 64 patients. At one year, mean whole blood ion levels were $1.61 \mu \mathrm{g} / \mathrm{L}$ (0.4 to 5.5) for chromium and $0.67 \mu \mathrm{g} / \mathrm{L}(0.23$ to 2.09$)$ for cobalt. The pre-operative ion levels, component size, female gender and the inclination of the acetabular component were inversely proportional to the values of chromium and/or cobalt ions at one year postoperatively. Other factors, such as age and level of activity, did not correlate with the levels of metal ions. We found that the levels of the ions in the serum were 1.39 and 1.37 times higher for chromium and cobalt respectively than those in the whole blood.

The levels of metal ions obtained may be specific to the hip resurfacing implant and reflect its manufacturing process.
\end{abstract}

A better understanding of the influence of the metallurgy and tribology on wear of the component and improved manufacturing technology have allowed the re-introduction of metalon-metal articulations in total hip replacement (THR). ${ }^{1}$ Excellent early clinical outcome has been reported with the new generation of metal-on-metal components. ${ }^{2-5}$ Retrieval studies of previous metal-on-metal bearings and contemporary implants have shown low rate of wear. ${ }^{6-13}$ These hard bearing surfaces are especially promising for young and active patients.

Although metal-on-metal bearings produce significantly less wear debris than metal-onpolyethylene bearing surfaces, the debris generated results in the body being exposed to metal ions for prolonged periods. ${ }^{14-18}$ Concerns exist over metal hypersensitivity, osteolysis, chromosomal mutation, carcinogenicity and fetal exposure to high ion levels. ${ }^{17,19}$ These matters require further investigation, particularly the long-term exposure in younger patients and the recognition that some patients may have unusually high ion levels. ${ }^{20,21}$

From tribological studies, joint simulation testing and clinical trials, it has been proposed that the extent of wear can be reduced by using components with a larger diameter with a high carbon content in the alloy $(0.2 \%)$, welladjusted clearance for the components, better implant sphericity and lower surface roughness. $^{22-27}$
The main objective of this prospective study was to measure whole blood chromium $(\mathrm{Cr})$ and cobalt $(\mathrm{Co})$ ion concentrations in patients with high carbon content, wrought-forged metal-on-metal surface replacement arthroplasty of the hip.

\section{Patients and Methods}

Between August 2003 and September 2005, all patients aged between 18 and 65 years scheduled for surface replacement arthroplasty were invited to participate. The investigation had ethical approval. Most of the patients were participants in a randomised clinical trial comparing THR and surface replacement arthroplasty. ${ }^{28-30}$ The exclusion criteria were single-stage bilateral hip replacement, known metal allergy, pregnancy, renal insufficiency, and the presence of other metallic implants. This resulted in 64 patients being included in the study. Their demographic data are summarised in Table I.

Surface replacement arthroplasty implant. The Durom resurfacing system (Zimmer, Winterthur, Switzerland) was used in all cases (Fig. 1). The femoral and acetabular components were made of wrought-forged, high carbon content $\mathrm{Cr}-\mathrm{Co}$ alloy $(\mathrm{Co}-28 \mathrm{Cr}-6 \mathrm{Mo}$, $0.20 \%$ to $0.25 \% \mathrm{C}$ ). The surface roughness $\left(R_{a}\right)$ was less than $0.005 \mu \mathrm{m}$, the deviation of the sphericity less than $10 \mu \mathrm{m}$ and the radial clearance was approximately $75 \mu \mathrm{m}$ (manu- 
Table I. Demographic data of the study population

\begin{tabular}{|c|c|}
\hline Number of patients & 64 \\
\hline \multicolumn{2}{|l|}{ Gender } \\
\hline Men:women & $42: 22$ \\
\hline Mean age in yrs (range; SD) & 48.6 (25 to $64 ; 8.9)$ \\
\hline Mean height in cm (range; SD) & 172 (150 to $188 ; 10.0)$ \\
\hline Mean weight in kg (range; SD) & 80.2 (47 to $131 ; 17.8)$ \\
\hline $\begin{array}{l}\text { Mean body mass index in } \mathrm{Kg} / \mathrm{m}^{2} \\
\text { (range; SD) }\end{array}$ & $27.1(17.6$ to $44.9 ; 5.6)$ \\
\hline \multicolumn{2}{|l|}{ Femoral head size in $\mathrm{mm}$} \\
\hline Mean (range) & 48.9 (40 to 58 ) \\
\hline Median; SD & $50 ; 3.97$ \\
\hline \multicolumn{2}{|l|}{ Pre-operative diagnoses (\%) } \\
\hline Primary osteoarthritis & $12(19)$ \\
\hline Protrusio & $3(5)$ \\
\hline Impinging hip & $31(48)$ \\
\hline Hip dysplasia & $8(12)$ \\
\hline Perthes' disease & $2(3)$ \\
\hline Inflammation & $4(6)$ \\
\hline Post-traumatic osteoarthritis & $3(5)$ \\
\hline Post-septic arthritis & $1(2)$ \\
\hline
\end{tabular}

facturer's data; Zimmer, Winterthur, Switzerland). The acetabular components are available in $2 \mathrm{~mm}$ increments with a constant wall thickness of $4 \mathrm{~mm}$, and match one femoral head component $8 \mathrm{~mm}$ smaller. Hybrid fixation was achieved with a cemented femoral component and a press-fit acetabular component with an external titanium coating applied by plasma spraying in a vacuum to produce a surface roughness of $20 \mu \mathrm{m} \leq \mathrm{Ra} \leq 50 \mu \mathrm{m}$ for secondary bone integration.

Blood, serum and erythrocyte sampling. Venous whole blood samples were collected pre-operatively, and at three, six, 12 and 24 months post-operatively. In addition, we collected serum and erythrocyte samples at 12 and 24 months. One week before blood collection, the patients were asked not to modify their exercise routine or to engage in new, strenuous activities, take new medications, or undergo other venous sampling. The vein was cannulated with a 22-gauge stainless steel needle (BD insyte, Ref. No. 381223; Beckton Dickinson infusion therapy systems Inc., Sandy, Utah), and the outer plastic cannula was left in place while the needle was discarded. To avoid contamination from the needle, the first $5 \mathrm{ml}$ of blood withdrawn were discarded. Three $5 \mathrm{ml}$ samples were collected in individual plastic syringes (BD syringes Luer Lok Tip, Ref No. 309604; Beckton Dickinson infusion therapy systems Inc., Franklin Lakes, New Jersey) by a research nurse. For serum and erythrocyte samples, whole blood was centrifuged at $3000 \mathrm{rpm}$ for 15 minutes. All samples were transferred to individual SARSTEDT polypropylene tubes (SARSTEDT Inc., St. Leonard, Canada) in a sterile environment and kept frozen at $-20^{\circ} \mathrm{C}$. All samples (whole blood,

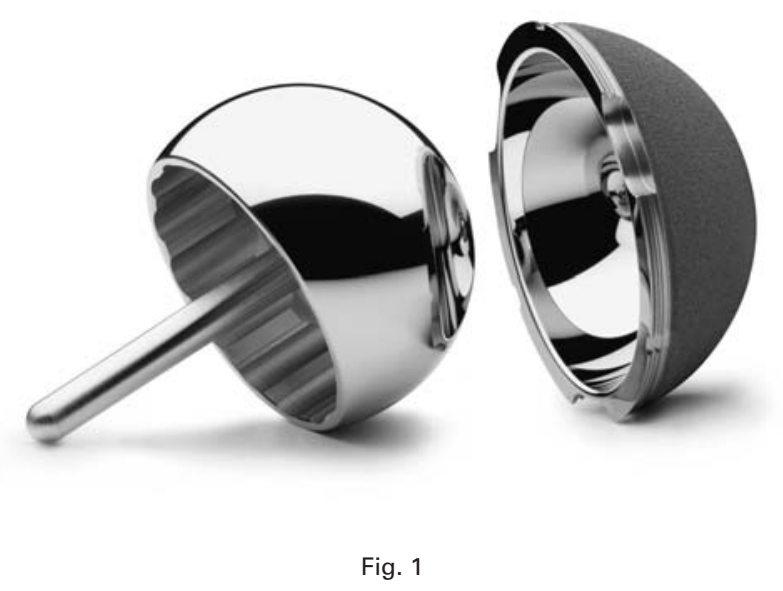

Durom hip resurfacing system.

serum and erythrocytes) were submitted for blinded analysis by Trace Element Laboratories, London, Ontario, Canada.

Trace element laboratory analysis. The concentrations of $\mathrm{Cr}$ and Co ions in the whole blood, serum and erythrocyte samples were measured in an Element 2 High-Resolution, Sector-Field, Inductively Coupled Plasma Mass Spectrophotometer (HR-SF-ICP-MS) (Thermo Fisher Scientific GmBH, Bremen, Germany). The detection limits were $0.1 \mu \mathrm{g} / \mathrm{L}$ for $\mathrm{Cr}$ and $0.01 \mu \mathrm{g} / \mathrm{L}$ for Co. The blood samples were exposed to concentrated nitric acid to digest protein and concentrated hydrogen peroxide to digest lipids. After dilution with water and internal standard yttrium 89, the final sample was introduced into the instrument and compared against aqueous standards with commercial blood controls to verify the results.

Other outcome measures. An additional questionnaire was completed by the patients at one year to identify all confounding factors that might potentially affect the blood levels of metal ions (Table II). ${ }^{31,32}$ The level of patient activity was assessed by the University California Los Angeles (UCLA) activity score. ${ }^{33}$ The Western Ontario McMasters (WOMAC) ${ }^{34}$ and the Merle D'Aubigné and Postel $^{35,36}$ scores were also calculated pre- and post-operatively. Anteroposterior radiographs of the pelvis, taken postoperatively and at the last follow-up, were analysed using a high-resolution (300 dpi) optical scanner (Vidar VXR-12; Vidar systems Herndon, Virginia) and processed with Imagika software (View Tech, CMC Corporation, New Jersey), which provided valid and reliable measurements of hip biomechanical parameters. ${ }^{37}$ The angle of inclination of the acetabular component was measured against the horizontal inter-teardrop line. ${ }^{38}$ The inclination of the femoral component (CCD angle) was measured between the axis of the stem of the femoral component and the anatomical axis of the shaft. Femoral offset was evaluated by the perpendicular distance from the centre line of the femur to the centre of rotation of the femoral head. ${ }^{39}$ 
Table II. Factors possibly affecting concentrations of $\mathrm{Cr}$ and $\mathrm{Co}$

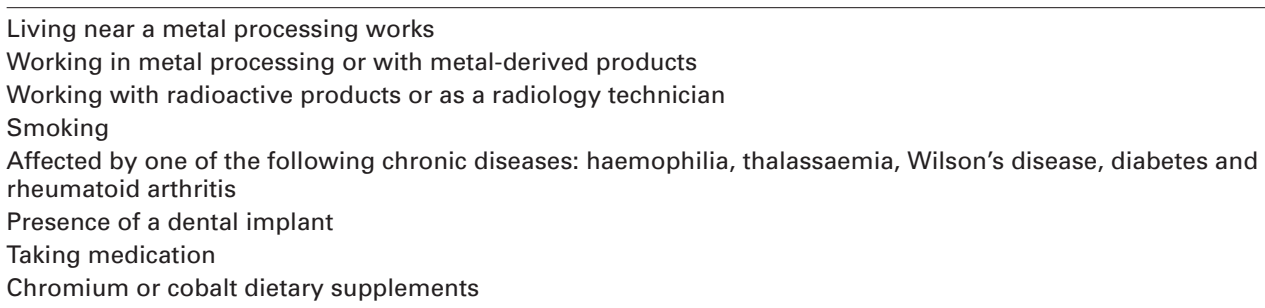

Chromium or cobalt dietary supplements

Table III. Radiological measurements and clinical scores (mean, range and standard deviation)

\begin{tabular}{|c|c|}
\hline Post-operative femoral offset in $\mathrm{mm}$ & $33.3(10.2$ to $46.7 ; 6.1)$ \\
\hline Post-operative angle of inclination $\left({ }^{\circ}\right)$ of the acetabular component & $46.7(31.2$ to $61.0 ; 6.4)$ \\
\hline Post-operative angle of inclination $\left({ }^{\circ}\right)$ of the femoral component & $141 \quad(121$ to $154 ; 8.4)$ \\
\hline \multicolumn{2}{|l|}{ WOMAC $^{*}$ score } \\
\hline Pre-operatively & $54.4(12$ to $84 ; 15.7)$ \\
\hline At one year post-operatively & $8.9(0$ to $73 ; 14.5)$ \\
\hline Mean, pre- vs post-operative value & $\mathrm{p}<0.0001$ \\
\hline \multicolumn{2}{|l|}{ Merle d'Aubigné Postel score } \\
\hline Pre-operatively & $10.8(5$ to $18 ; 2.9)$ \\
\hline At one year post-operatively & $16.8(11$ to $18 ; 2.1)$ \\
\hline Mean, pre- $v s$ post-operative value & $\mathrm{p}<0.0001$ \\
\hline \multicolumn{2}{|l|}{ UCLA $^{\dagger}$ activity score } \\
\hline At one year post-operatively & $7.84(4$ to $10 ; 1.8)$ \\
\hline
\end{tabular}

* WOMAC, Western Ontario McMasters arthritis index

† UCLA, University of California, Los Angeles

Table IV. Whole blood metal ions in $\mu \mathrm{g} / \mathrm{L}$

\begin{tabular}{|c|c|c|c|c|c|c|c|c|c|c|}
\hline & \multirow{2}{*}{\multicolumn{2}{|c|}{$\begin{array}{l}\text { Pre-operative } \\
45 / 64^{*}\end{array}$}} & \multirow{2}{*}{\multicolumn{2}{|c|}{$\frac{3 \text { mths }}{50 / 62^{*}}$}} & \multirow{2}{*}{\multicolumn{2}{|c|}{$\frac{6 \text { mths }}{51 / 61^{*}}$}} & \multirow{2}{*}{\multicolumn{2}{|c|}{$\frac{12 \text { mths }}{53 / 59 *}$}} & \multirow{2}{*}{\multicolumn{2}{|c|}{$\frac{24 \text { mths }}{27 / 55^{*}}$}} \\
\hline & & & & & & & & & & \\
\hline & $\mathrm{Cr}$ & Co & $\mathrm{Cr}$ & Co & $\mathrm{Cr}$ & Co & $\mathrm{Cr}$ & Co & $\mathrm{Cr}$ & Co \\
\hline Mean & 0.92 & 0.15 & 2.01 & 0.90 & 1.89 & 0.80 & 1.61 & 0.67 & 1.37 & 0.59 \\
\hline Standard deviation & 0.54 & 0.15 & 1.12 & 0.42 & 0.96 & 0.32 & 1.04 & 0.35 & 0.65 & 0.26 \\
\hline Minimum & 0.40 & 0.06 & 0.60 & 0.25 & 0.60 & 0.25 & 0.40 & 0.23 & 0.60 & 0.20 \\
\hline Maximum & 2.70 & 1.05 & 6.50 & 1.95 & 4.90 & 1.61 & 5.50 & 2.09 & 3.00 & 1.22 \\
\hline
\end{tabular}

Statistical analysis. All statistical analyses were performed with Systats 11.0 for Windows (Systat Software Inc., Point Richmond, California). Student's $t$-tests and the chisquared tests were used to compare the different subgroups for continuous and categorical variables, respectively. Repeated-measure analyses of variance (ANOVA) were used to assess ion levels over time. Simple regression analyses were used to evaluate the relationship of different factors to the levels of $\mathrm{Cr}$ and $\mathrm{Co}$ ions. Stepwise multivariate regression analysis was then performed to identify independent predictors of ion levels. Because of the limited number of subjects, only those demographic factors thought to influence outcome and pre-operative ion levels were tested in the model as potential predictors. Concentrations of the ions in whole blood, serum and erythrocytes were compared with paired $t$-tests and their hypothesised ratio of 1 was tested with single-sample tests. Levene's test for equality of variance was used to confirm the normal distribution of the data sets in all cases. Continuous variables are presented as means and ranges, and categorical variables as a frequency and percentage. The statistical significance was defined as $\mathrm{p}<0.05$.

\section{Results}

The clinical scores and radiological measurements are presented in Table III. The pre- and post-operative concentrations of $\mathrm{Cr}$ and $\mathrm{Co}$ in whole blood are summarised in Table IV and Figure 2. During the period of follow-up we 


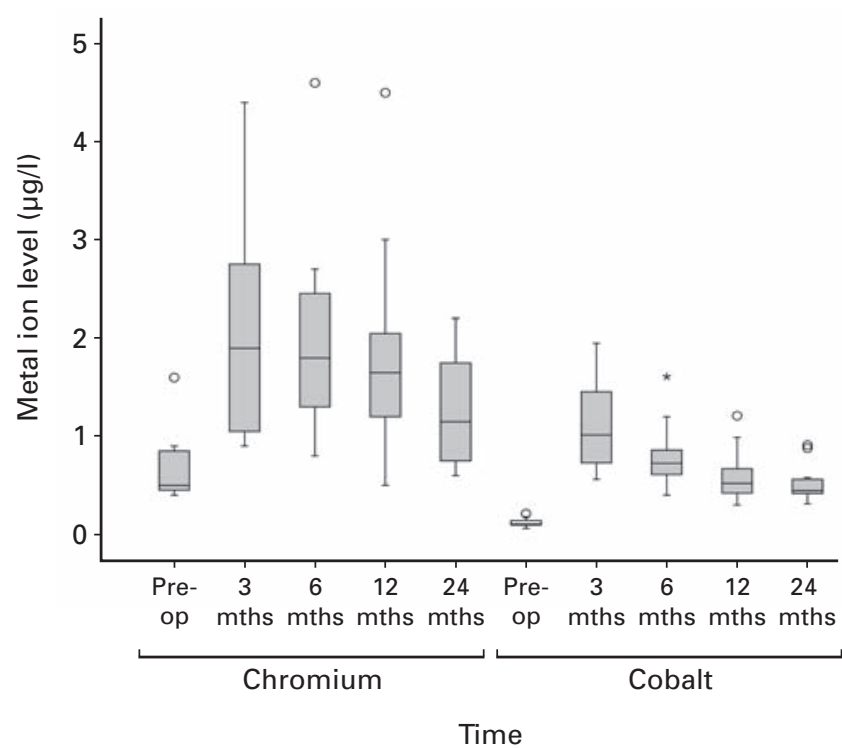

Fig. 2

Box plot chart of the concentrations of chromium (Cr) and cobalt (Co) in whole blood pre-operatively and at three, six, 12 and 24 months postoperatively. Box lengths represent the interquartile range (first to third quartiles). The line in the centre of the boxes represents the median value. Data represented by 'o' are outliers (being more than 1.5 to 3.0 times the interquartile range over the third quartile), and data represented by '*' are extreme values (being more than three times the interquartile range over the third quartile).

stopped blood collection in nine patients, eight of whom had their contralateral hip operated upon or received another metal implant, and the other underwent revision of a loose femoral component. Other reasons for incomplete collection of data at the different periods of follow-up are presented in Table V.

A statistically significant rise occurred in the concentrations of $\mathrm{Cr}$ and $\mathrm{Co}$ in the whole blood before operations and at three-months (paired $t$-test, $\mathrm{p}=0.0006$ and $\mathrm{p}<0.001$, respectively). A significant decrease in $\mathrm{Cr}$ concentration was only seen when comparing one- and twoyear evaluations (paired $t$-test, $\mathrm{p}=0.0416$ ). Between the three- and six-month (paired $t$-test, $\mathrm{p}=0.7848$ ) and sixmonth and one year (paired $t$-test, $\mathrm{p}=0.2377$ ) evaluations, no significant changes of $\mathrm{Cr}$ concentrations were observed. In contrast, the Co concentrations declined significantly between the three- and six-month (paired $t$-test, $\mathrm{p}=0.0003$ ) and the six-month and one-year (paired $t$-test, $\mathrm{p}=0.0114$ ) evaluations, but there was no statistically significant difference between the one- and the two-year evaluations (paired $t$-test, $\mathrm{p}=0.1192$ ). The one- and two-year mean levels of $\mathrm{Cr}$ were 1.8 times and 1.5 times higher than the mean preoperative values, respectively, and increased by a factor of 4.5 and 3.9, respectively, for the mean values of Co (Table IV).

All demographic and pre-operative factors, including side, gender, age, height, weight, body mass index (BMI),

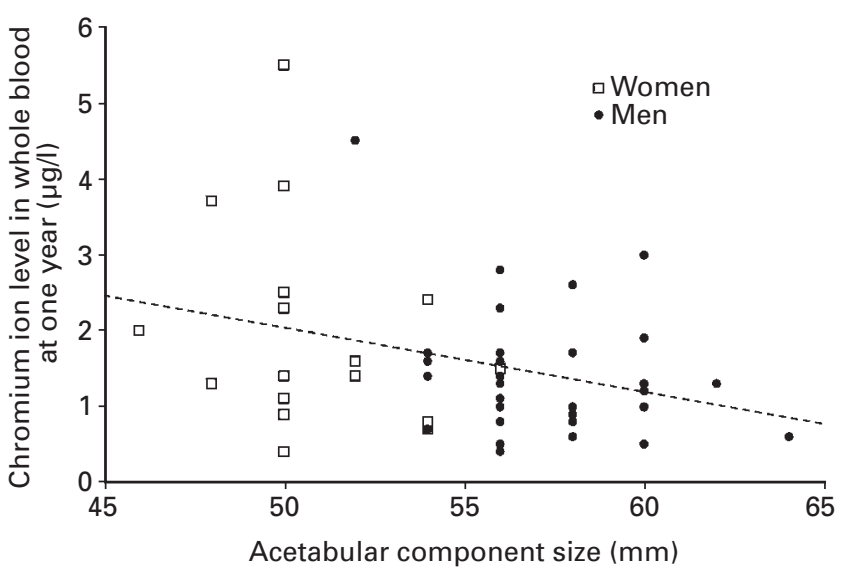

Fig. 3

Analysis of variance regression analysis between chromium ion levels in whole blood at one year and size of the acetabular component $16 \mathrm{~mm}$ larger than the femoral component diameter).

UCLA activity score, WOMAC score, bearing diameter, offset, acetabular component inclination angle, femoral component inclination angle as well as pre-operative $\mathrm{Cr}$ and Co ion levels, were tested univariately to assess their potential influence on $\mathrm{Cr}$ and $\mathrm{Co}$ ion levels in whole blood at one year after operation. Univariate results showed that, with regression analysis, the bearing diameter of the component significantly influenced the levels of $\mathrm{Cr}$ ions at one year (Pearson's correlation coefficient $\mathrm{p}=0.0183$, $\mathrm{R}^{2}=0.089$ for Cr, Fig. 3 ) and this correlation was inversely proportional. It was not significant for levels of Co at one year (Pearson's correlation coefficient $\mathrm{p}=0.0934, \mathrm{R}^{2}=$ 0.05). Female gender was significantly associated with increased levels of Co at one year (ANOVA, $\mathrm{p}=0.0501$ ) and two years (ANOVA, $\mathrm{p}=0.0216$ ), but not with levels of $\mathrm{Cr}$ (one year ANOVA, $\mathrm{p}=0.1416$; and two years $\mathrm{p}=0.1556$ ). Comparing the means for both genders, levels of Co at oneyear were significantly different $(0.60$ for males and 0.80 for females, ANOVA, p = 0.05), but there was no significant difference in $\mathrm{Cr}$ (1.46 for males and 1.89 for females, $\mathrm{p}=0.16)$. Males and females differed significantly in height (ANOVA, $\mathrm{p}<0.0001$ ), weight (ANOVA, $\mathrm{p}<0.0001$ ), BMI $(\mathrm{p}=0.0373)$, mean femoral offset $(\mathrm{p}=0.0286)$ and mean femoral head component size (ANOVA, $\mathrm{p}<0.0001,44.8 \mathrm{~mm}$ for females and $51.1 \mathrm{~mm}$ for males). The mean pre-operative $\mathrm{Cr}$ and $\mathrm{Co}$ levels were not significantly different between genders for $\mathrm{Cr}$ and Co (ANOVA, $\mathrm{p}=0.9696$ and $\mathrm{p}=0.3598)$. Applying stepwise multivariate analysis, only female gender, the pre-operative concentration of Co and the inclination of the acetabular component were found to be independent predictors of the concentration of Co in whole blood at one year in a model yielding a multiple $\mathrm{R}^{2}$ of $0.250(\mathrm{p}=0.021)$. No multivariate model attained statistical significance for levels of $\mathrm{Cr}$ ions at one year. 
Table V. Reasons for incomplete data at each follow-up interval

\begin{tabular}{|c|c|c|c|c|c|}
\hline & \multirow[b]{2}{*}{ Pre-operative } & \multicolumn{4}{|c|}{ Months post-operatively } \\
\hline & & 3 & 6 & 12 & 24 \\
\hline Number of subjects still included & 64 & 62 & 61 & 59 & 55 \\
\hline Number of collected samples & 45 & 50 & 51 & 53 & 27 \\
\hline \multicolumn{6}{|l|}{ Reasons for missing samples } \\
\hline Twice failed venesection & 5 & 3 & 4 & 2 & 3 \\
\hline $\begin{array}{l}\text { Venesection already undertaken on the same day outside the } \\
\text { protocol }^{*}\end{array}$ & 4 & & & & \\
\hline Patient non-attendance & & 4 & 3 & 1 & \\
\hline Follow-up interval not yet reached & & & & 1 & 21 \\
\hline Complication requiring revision & & 1 & & & \\
\hline Patient received other metal implant & & 1 & 1 & 2 & 4 \\
\hline Research assistant unavailable for venesection & 10 & 3 & 2 & & \\
\hline
\end{tabular}

* blood collection was done for other reasons on the same day

Table VI. Mean chromium and cobalt concentrations in $\mu \mathrm{g} / \mathrm{L}$ in whole blood serum and erythrocytes, of the same subjects at between one or two years after implantation

\begin{tabular}{|c|c|c|c|c|c|}
\hline & Whole blood & Serum & Erythrocytes & $\begin{array}{l}\text { Serum: } \\
\text { whole blood ratio }\end{array}$ & $\begin{array}{l}\text { Erythrocytes: } \\
\text { whole blood ratio }\end{array}$ \\
\hline Number & 41 & 34 & 22 & 34 paired samples & 22 paired samples \\
\hline \multicolumn{6}{|l|}{ Chromium } \\
\hline Mean (range) & $1.33(0.40$ to 4.50$)$ & 1.59 (0.61 to 3.23$)$ & $0.92(0.30$ to 2.60$)$ & 1.39 (0.41 to 2.46$)$ & $0.98(0.11$ to 6.50$)$ \\
\hline \multicolumn{6}{|l|}{ Cobalt } \\
\hline Mean (range) & $0.63(0.25$ to 1.52$)$ & $0.83(0.33$ to 1.45$)$ & $0.46(0.20$ to 0.88$)$ & $1.37(0.72$ to 1.80$)$ & $0.76(0.47$ to 1.57$)$ \\
\hline
\end{tabular}

A comparison was made of mean $\mathrm{Cr}$ and Co concentrations in the whole blood, serum and erythrocytes in the same patients at the one- or two-year follow-ups (Table VI). A significant difference was identified between whole blood and serum concentrations of $\mathrm{Cr}$ (paired $t$-test, $\mathrm{p}=0.0176$ ) and Co (paired $t$-test, $\mathrm{p}<0.0001$ ), and between whole blood and erythrocyte concentrations of Co (paired $t$-test, $p=0.0003)$. No significant difference was apparent between the whole blood and the erythrocyte concentration of $\mathrm{Cr}$ (paired $t$-test, $\mathrm{p}=0.0601$ ). The mean ion levels in the serum exceeded the mean levels in the whole blood by 1.39 times for $\mathrm{Cr}$ and 1.37 times for Co. In contrast, the mean ion levels in the erythrocytes were only $0.98 \%$ of the mean whole blood level for $\mathrm{Cr}$ and $\mathbf{0 . 7 6 \%}$ for Co. Pearson's correlation coefficient between $\mathrm{Cr}$ concentration in whole blood and serum was 0.552 (Pearson's correlation coefficient, $\mathrm{p}=0.0026)$ and $0.087(\mathrm{p}=0.7163)$ for whole blood and erythrocytes. Between the concentration of Co in the whole blood and the serum, Pearson's correlation coefficient was $0.857(\mathrm{p}<0.0001)$ and $0.801(\mathrm{p}<0.0001)$ for whole blood and erythrocytes. Equivalent concentrations of ions in the serum and whole blood should have yielded a ratio of 1.0. A one-sample test comparing the ratios found to the hypothesised equivalence (ratio of 1.0) showed significant differences for both $\mathrm{Cr}(\mathrm{p}=0.0002)$ and Co $(p<0.0001)$, indicating an over-estimation of serum compared with whole blood.

Except for the patient requiring revision due to femoral loosening, none had mechanical problems or symptoms.
The single failure had a large cyst pre-operatively in the femoral head, and complete penetration of the head with cement was observed at implant retrieval. Plain radiological analysis did not reveal any patient with narrowing of the femoral neck, lucent lines around the femoral stem or loosening of the components at a mean follow-up of 32 months (21 to 44 ).

\section{Discussion}

The metal ion levels found after THR have been reported. ${ }^{18,40,41}$ These may be related, at least in part, to wear of the bearing surface and serve as an indicator of the in vivo performance of metal-on-metal bearing surfaces. However, comparison within the literature is complicated by differences in the sampling (whole blood, serum, erythrocytes or urine), the laboratory methods, the presentation of the results and the various types of combinations of implant. ${ }^{20,31,40,42,43}$

To overcome these problems, we sent 41 whole blood and 34 serum and/or 22 erythrocyte samples for analysis, obtained at the same time from the same patients at one or two years of follow-up. By doing so, we were able to ascertain the concentration ratios between the three media (Table VI) to enable comparison of our results with other published studies. However, we do not know whether these correlating factors will be stable over time. For this reason, we have attempted to confine direct comparison of data to reports within a similar period of follow-up. 
Table VII. Review of recent literature on serum metal ion concentrations after surface replacement arthroplasty

\begin{tabular}{|c|c|c|c|c|}
\hline & \multirow[b]{2}{*}{$\begin{array}{l}\text { Chromium ion level } \\
\text { ( } \mu \mathrm{g} / \mathrm{L}) \text { (range) }\end{array}$} & \multirow[b]{2}{*}{$\begin{array}{l}\text { Cobalt ion level } \\
(\mu \mathrm{g} / \mathrm{L}) \text { (range) }\end{array}$} & \multicolumn{2}{|c|}{ Increase over pre-operative level } \\
\hline & & & Chromium & Cobalt \\
\hline \multicolumn{5}{|l|}{ Our results* } \\
\hline \multicolumn{5}{|l|}{ Durom $(n=53)$} \\
\hline Mean at 12 months post-operatively & $2.2(0.56$ to 7.66$)$ & $0.9(0.32$ to 2.91$)$ & 1.8 & 4.4 \\
\hline Pre-operative level & 1.26 & 0.21 & & \\
\hline \multicolumn{5}{|l|}{ Back et $\mathrm{al}^{20}$} \\
\hline \multicolumn{5}{|l|}{$\mathrm{BHR}^{\dagger}(\mathrm{n}=16)$} \\
\hline Mean at 12 months post-operatively & $4.0(0.6$ to 9.9$)$ & $2.4(1.1$ to 6.7$)$ & 12.8 & 7.1 \\
\hline Pre-operative level & 0.3 & 0.3 & & \\
\hline \multicolumn{5}{|l|}{ Clarke et $\mathrm{al}^{31}$} \\
\hline BHR $(n=16)$. Median & $2.6(1.5$ to 8.6$)$ & $2.1(0.8$ to 8.5$)$ & $N A^{\ddagger}$ & NA \\
\hline Cormet $2000(n=6)$. Median 16 months post-operatively & $4.2(1.3$ to 6.7$)$ & $3.0(1.2$ to 6.9$)$ & NA & NA \\
\hline \multicolumn{5}{|c|}{ Jacobs et $\mathrm{al}^{41}$} \\
\hline $\begin{array}{l}\text { Mean of } 12.4 \text { months post-operatively for the McMinn } \\
(n=4) \text { and Wagner }(n=2) \text { combined }\end{array}$ & $3.9(2.6$ to 5.7$)$ & $3.8(1.0$ to 9.6$)$ & NA & NA \\
\hline
\end{tabular}

Jacobs et $\mathrm{al}^{41}$ recorded mean serum levels of $2.9 \mu \mathrm{g} / \mathrm{L}$ for $\mathrm{Cr}$ and $3.8 \mu \mathrm{g} / \mathrm{L}$ for Co in a small number of two different surface replacement arthroplasty implants at various periods of follow-up. However, no pre-operative ion concentrations were recorded. More recently, Back et $\mathrm{al}^{20}$ quantified the pre- and post-operative serum $\mathrm{Cr}$ and $\mathrm{Co}$ levels of 16 patients with Birmingham Hip Replacements (Smith and Nephew, Memphis, Tennessee). At one year a mean level of CR of $4.0 \mu \mathrm{g} / \mathrm{L}(0.6$ to 9.9$)$ and a mean level of Co of $2.4 \mu \mathrm{g} / \mathrm{L}$ (1.1 to 6.7) were observed (Table VII). These values are 12.8 times the mean pre-operative level for $\mathrm{Cr}$ and 7.1 times for Co. A significant decrease in ion concentrations was noted between six months and two years $(\mathrm{p}=0.0068)$. The maximum levels found were up to $9.9 \mu \mathrm{g} /$ $\mathrm{L}$ for $\mathrm{Cr}$ and $6.7 \mu \mathrm{g} / \mathrm{L}$ for Co. Clarke et $\mathrm{al}^{31}$ published results comparing the median $\mathrm{Cr}$ and $\mathrm{Co}$ serum concentrations 16 months after Birmingham hip replacement and Cormet 2000 surface replacement arthroplasty (Corin Group PLC, Cirencester, United Kingdom). No difference was apparent between the two types of implant. They recorded significant post-operative increases in the concentrations of Cr and Co (Table VII).

To compare our findings with other published data at a similar period of follow-up, we converted our mean whole blood results at one year with the correction factor for serum/whole blood ratios derived from a proportion of our patients. This produced mean serum values at one year of $2.2 \mu \mathrm{g} / \mathrm{L}$ and $0.94 \mu \mathrm{g} / \mathrm{L}$ for chromium and cobalt, respectively. These results are much lower than other published values and represent 1.8 and 4.4 times the pre-operative levels for $\mathrm{Cr}$ and $\mathrm{Co}$, respectively (Table VII). ${ }^{20,31,41}$ In the evaluation of ion production in metal-on-metal implants mean and median values might be of lesser importance than the range of data. Back et $\mathrm{al}^{20}$ using the Birmingham hip replacement, described direct-measurement of serum maximum levels of $9.9 \mu \mathrm{g} / \mathrm{L}$ for $\mathrm{Cr}$, and $6.7 \mu \mathrm{g} / \mathrm{L}$ for Co. These extreme values might have a greater risk of long-term sequelae to metal ion exposure. In our investigation, at one year, the maximum derived serum levels were $7.66 \mu \mathrm{g} / \mathrm{L}$ for $\mathrm{Cr}$ and $2.91 \mu \mathrm{g} / \mathrm{L}$ for Co (whole blood converted serum results).

We were unable to find a significant correlation between $\mathrm{Cr}$ and Co levels with factors such as the activity level, as represented by the UCLA score, age, weight, BMI and femoral offset. This is similar to the report from Heisel et al, ${ }^{44}$ who found no correlation between activity and concentrations of serum ions. This observation on large metal-onmetal bearings might allay some concerns about restricting their use in young and active subjects requiring hip replacement.

Different factors such as the quality of the surface finish, ${ }^{24}$ component sphericity, radial clearance, manufacturing process (forged $v s$ cast metal), and metal carbon content may influence the wear of metal-on-metal bearings. ${ }^{22}$ For the same bearing clearance, tribology shows that a large diameter component would create a thicker fluid film between the femoral head and the acetabular component surface. ${ }^{25}$ With a thicker fluid film, less contact would occur between the components and wear would be reduced. However, there are no published in vivo results to confirm this. The evidence to date reveals high $\mathrm{Cr}$ and Co ion levels with hip resurfacing compared with $28 \mathrm{~mm}$ metal-on-metal articulations. ${ }^{20,31,40,41}$

In our study, we noted a significant correlation between the diameter of the components in surface replacement arthroplasty and $\mathrm{Cr}$ ion concentrations at one year after operation $(\mathrm{p}=0.0183)$. However, this correlation with $\mathrm{R}^{2}=0.089$ should be considered with caution. By univari- 
ate analysis, we also noted that females were weakly associated with higher Co levels at one year. In the multivariate model, the effect of female gender, pre-operative ion levels and the angle of acetabular inclination were significantly associated with increased Co levels $\left(\mathrm{p}=0.021, \mathrm{R}^{2}=0.250\right)$ at one year. Our limited number of subjects does not allow us to draw strong conclusions on the associated factors that might influence individual post-operative levels of metal ions. However, a trend toward smaller component size and female gender as factors increasing metal ion levels seems to be present with an association between small components and female gender (Fig. 3). However, the difference in ion levels found between genders may be secondary to differences in metal ion metabolism between genders (different lean body mass, cellular or extra cellular storage or renal excretion). Another explanation could be limitations in implant manufacturing precision. When aiming for a specific component clearance, variations may occur; smaller components may be more sensitive to such variations. The other interesting finding is the association of pre-operative levels of Co ions and the post-operative results at one year.

The mean levels of cobalt ions in serum of $0.9 \mu \mathrm{g} / \mathrm{L}$ at one year in our investigation were similar to the mean results of $1.0 \mu \mathrm{g} / \mathrm{L}$ obtained with eight well-functioning McKee-Farrar implants (Howmedica International Inc., Limerick, Ireland) after more than 20 years of implantation $^{41}$ or Metasul (Zimmer) $28 \mathrm{~mm}$ metal-onmetal THR $(1.0 \mu \mathrm{g} / \mathrm{L}$ at one year, and $0.7 \mu \mathrm{g} / \mathrm{L}$ at a median of five years). ${ }^{40}$ Levels in that range were not found to be associated with any increased risk of cancer over a mean of 15.7 years in a retrospective study by Visuri et al. ${ }^{19}$

The mean and range of serum $\mathrm{Cr}$ and Co ion levels, measured in patients after wrought-forged high carbon content, metal-on-metal surface replacement arthroplasty implants in this study, are lower than have been reported with some other surface replacement arthroplasty implants.

We acknowledge the clinical work and technical support of Daniel Lusignan, RN clinical research assistant.

No benefits in any form have been received or will be received from a commercial party related directly or indirectly to the subject of this article.

\section{References}

1. Weber BG. Experience with the Metasul total hip bearing system. Clin Orthop 1996;329(Suppl):69-77.

2. Amstutz HC, Beaule PE, Dorey FJ, et al. Metal-on-metal hybrid surface arthroplasty: two to six-year follow-up study. J Bone Joint Surg [Am] 2004;86-A:28-39.

3. Treacy RB, McBryde CW, Pynsent PB. Birmingham hip resurfacing arthroplasty: a minimum follow-up of five years. J Bone Joint Surg [Br] 2005;87-B:167-70.

4. Pollard TC, Baker RP, Eastaugh-Waring SJ, Bannister GC. Treatment of the young active patient with osteoarthritis of the hip: a five- to seven-year comparison of hybrid total hip arthroplasty and metal-on-metal resurfacing. J Bone Joint Surg [Br] 2006;88-B:592-600.

5. Mont MA, Ragland PS, Etienne G, Seyler TM, Schmalzried TP. Hip resurfacing arthroplasty. J Am Acad Orthop Surg 2006;14:454-63.

6. August AC, Aldam CH, Pynsent PB. The McKee-Farrar hip arthroplasty: a longterm study. J Bone Joint Surg [Br] 1986;68-B:520-7.

7. Jantsch S, Schwagerl W, Zenz P, Semlitsch M, Fertschak W. Long-term results after implantation of McKee-Farrar total hip prostheses. Arch Orthop Trauma Surg 1991;110:230-7

8. Brown SR, Davies WA, DeHeer DH, Swanson AB. Long-term survival of McKeeFarrar total hip prostheses. Clin Orthop 2002;402:157-63.
9. Goldsmith AA, Dowson D, Isaac GH, Lancaster JG. A comparative joint simulator study of the wear of metal-on-metal and alternative materials combinations in hip replacements. Proc Inst Mech Eng [H]2000;214:39-47.

10. Wagner $\mathbf{M}$, Wagner $\mathbf{H}$. Medium-term results of a modern metal-on-metal system in total hip replacement. Clin Orthop 2000;379:123-33.

11. Sieber HP, Rieker CB, Kottig P. Analysis of 118 second-generation metal-on-metal retrieved hip implants. J Bone Joint Surg [Br] 1999;81-B:46-50.

12. Schmalzried TP, Peters PC, Maurer BT, Bragdon CR, Harris WH. Long-duration metal-on-metal total hip arthroplasties with low wear of the articulating surfaces. $J$ Arthroplasty 1996;11:322-31.

13. McKellop H, Park SH, Chiesa R, et al. In vivo wear of three types of metal on metal hip prostheses during two decades of use. Clin Orthop 1996;329(Suppl):128-40.

14. Beaule PE, Campbell P, Amstutz HC. Metallosis and metal-on-metal bearings. J Bone Joint Surg [Am] 2000;82-A:751-2.

15. Milosev I, Pisot V, Campbell P. Serum levels of cobalt and chromium in patients with Sikomet metal-on-metal total hip replacements. J Orthop Res 2005;23:526-35.

16. MacDonald SJ. Can a safe level for metal ions in patients with metal-on-metal total hip arthroplasties be determined? J Arthroplasty 2004;19(Suppl 3):71-7.

17. MacDonald SJ. Metal-on-metal total hip arthroplasty: the concerns. Clin Orthop 2004; 429:86-93.

18. Savarino L, Granchi D, Ciapetti G, et al. Ion release in patients with metal-onmetal hip bearings in total joint replacement: a comparison with metal-on-polyethylene bearings. J Biomed Mater Res 2002;63:467-74.

19. Visuri T, Pukkala E, Paavolainen P, Pulkkinen P, Riska EB. Cancer risk after metal on metal and polyethylene on metal total hip arthroplasty. Clin Orthop 1996;329(Suppl):280-9.

20. Back DL, Young DA, Shimmin AJ. How do serum cobalt and chromium levels change after metal-on-metal hip resurfacing? Clin Orthop 2005;438:177-81.

21. Skipor AK, Campbell PA, Patterson LM, et al. Serum and urine metal levels in patients with metal-on-metal surface arthroplasty. J Mater Sci Mater Med 2002;13:1227-34

22. Rieker CB, Schon R, Konrad R, et al. Influence of the clearance on in-vitro tribology of large diameter metal-on-metal articulations pertaining to resurfacing hip implants. Orthop Clin North Am 2005;36:135-42.

23. Liu F, Jin ZM, Hirt F, et al. Effect of wear of bearing surfaces on elastohydrodynamic lubrication of metal-on-metal hip implants. Proc Inst Mech Engh [H]2005;219:319-28.

24. Rieker CB, Schon R, Kottig P. Development and validation of a second-generation metal-on-metal bearing: laboratory studies and analysis of retrievals. J Arthroplasty 2004;19(Suppl 3):5-11

25. Smith SL, Dowson D, Goldsmith AA. The effect of femoral head diameter upon lubrication and wear of metal-on-metal total hip replacements. Proc Inst Mech Eng [H] 2001;215:161-70.

26. Ito $\mathbf{H}$, Minami A, Matsumo T, et al. The sphericity of the bearing surface in total hip arthroplasty. J Arthroplasty 2001;16:1024-9.

27. Chan FW, Bobyn JD, Medley JB, Krygier JJ, Tanzer M. Wear and lubrication of metal-on-metal hip implants. Clin Orthop 1999;369:10-24.

28. Vendittoli PA, Lavigne M, Roy AG, Lusignan D. A prospective, randomized clinical trial comparing metal-on-metal total hip arthroplasty and metal-on-metal total hip resurfacing in patients less than 65 years old. Hip Int 2006;16(Suppl 4):73-81.

29. Vendittoli PA, Lavigne M, Girard J, Roy AG. A randomised study comparing resection of acetabular bone at resurfacing and total hip replacement. J Bone Joint Surg [Br] 2006;88-B:997-1002

30. Girard J, Lavigne M, Vendittoli PA, Roy AG. Biomechanical reconstruction of the hip: a randomized study comparing total hip resurfacing and total hip arthroplasty. $J$ Bone Joint Surg [Br] 2006;88-B:721-6.

31. Clarke MT, Lee PT, Arora A, Villar RN. Levels of metal ions after small- and largediameter metal-on-metal hip arthroplasty. J Bone Joint Surg [Br] 2003;85-B:913-17.

32. Brodner W, Grohs JG, Bitzan P, et al. Serum cobalt and serum chromium level in 2 patients with chronic renal failure after total hip prosthesis implantation with metal-guided gliding contract. Z Orthop Ihre Grenzgeb 2000;138:425-9 (in German).

33. Zahiri CA, Schmalzried TP, Szuszcewicz ES, Amstutz HC. Assessing activity in joint replacement patients. J Arthroplasty 1998;13:890-5.

34. Bellamy N, Buchanan WW, Goldsmith CH, Campbell J, Stitt LW. Validation study of WOMAC: a health status instrument for measuring clinically important patient relevant outcomes to antirheumatic drug therapy in patients with osteoarthritis of the hip or knee. J Rheumatol 1988;15:1833-40.

35. D'Aubigne RM, Postel M. Functional results of hip arthroplasty with acrylic prostheses. J Bone Joint Surg [Am]1954;36-A:451-75.

36. D'Aubigne RM. Numerical classification of the function of the hip.1970. Rev Chir Orthop Reparatrice Appar Mot 1990;76:371-4 (in French). 
37. Girard J, Touraine D, Soenen M, et al. Measurement of head penetration on digitalized radiographs: reproducibility and accuracy. Rev Chir Orthop Reparatrice Appar Mot 2005;91:137-42 (in French).

38. Massin P, Schmidt L, Engh CA. Evaluation of cementless acetabular componen migration: an experimental study. J Arthroplasty 1989;4:245-51.

39. McGrory BJ, Morrey BF, Cahalan TD, An KN, Cabanela ME. Effect of femora offset on range of motion and abductor muscle strength after total hip arthroplasty. $J$ Bone Joint Surg [Br] 1995;77-B:865-9.

40. Brodner W, Bitzan P, Meisinger V, et al. Serum cobalt levels after metal-on-metal total hip arthroplasty. J Bone Joint Surg [Am] 2003;85-A:2168-73.
41. Jacobs JJ, Skipor AK, Doorn PF, et al. Cobalt and chromium concentrations in patients with metal on metal total hip replacements. Clin Orthop 1996:329(Suppl):256-63.

42. MacDonald SJ, McCalden RW, Chess DG, et al. Metal-on-metal versus polyethylene in hip arthroplasty: a randomized clinical trial. Clin Orthop 2003;406:282-96.

43. MacDonald SJ, Brodner W, Jacobs JJ. A consensus paper on metal ions in metal-on-metal hip arthroplasties. J Arthroplasty 2004;19(Suppl 3):12-16.

44. Heisel C, Silva M, Skipor AK, Jacobs JJ, Schmalzried TP. The relationship between activity and ions in patients with metal-on-metal bearing hip prostheses. Bone Joint Surg [Am]2005;87-A:781-7. 